\title{
Effects of Diet Selection by Goats Grazing on the Vegetation of a Protected Pine Forest in Doñana Natural Park (SW Spain)
}

\author{
Juan Manuel Mancilla-Leytón, Rocío Fernández-Alés and Ángel Martín Vicente * \\ Departamento de Biología Vegetal y Ecología, Facultad de Biología, Universidad de Sevilla, Apdo 1095, \\ 41080 Sevilla, Spain; jmancilla@us.es (J.M.M.-L.); rocio@us.es (R.F.-A.) \\ * Correspondence: angelm@us.es; Tel.: +34-954-557-063
}

Citation: Mancilla-Leytón, J.M.; Fernández-Alés, R.; Martín Vicente, Á. Effects of Diet Selection by Goats Grazing on the Vegetation of a Protected Pine Forest in Doñana Natural Park (SW Spain). Sustainability 2021, 13, 3950. https:// doi.org/10.3390/su13073950

Academic Editor: Lewis Holloway

Received: 8 March 2021

Accepted: 31 March 2021

Published: 2 April 2021

Publisher's Note: MDPI stays neutral with regard to jurisdictional claims in published maps and institutional affiliations.

Copyright: (C) 2021 by the authors. Licensee MDPI, Basel, Switzerland. This article is an open access article distributed under the terms and conditions of the Creative Commons Attribution (CC BY) license (https:// creativecommons.org/licenses/by/ $4.0 /)$.

\begin{abstract}
We investigated the relationship between feeding selection by goats and changes in plant species abundance in the shrubland of a pine forest in Doñana Natural Park along three years. The abundance of the shrub species was measured using the point-intercept method. Goat preferences for shrub species were determined through direct observation. Goats showed selective feeding, since their browsing behavior was not related to species abundance. Myrtus communis was the overall preferred species (almost half of the bites belonged to this species, despite its low abundance) throughout the monitored years and seasons. Half of the species were selected some years while discarded others; two species were never grazed (Daphne gnidium and Thymus mastichina) and nine others were always ingested below their abundance. Within a year, species were consumed in certain seasons but not in others. The detected changes in species abundance were not related to the feeding preferences of the goats. The influence that grazing selectivity exerts on vegetation composition and abundance has long been recognized, but our study suggests that the mechanical effect of grazing herbivores on vegetation (pawing, scratching, and lying) may portrait a more important role than attributed to date.
\end{abstract}

Keywords: shrub; Pinus pinea; Payoya; direct observation; Ivlev's selectivity index

\section{Introduction}

Grazing by domestic and wild ungulates is the most globally widespread land use [1]. Along with burning, grazing is the greatest vegetation disturbance activity in terms of area and biomass loss [2], significantly influencing current vegetation composition and structure [3].

Grazing selectivity has been considered to greatly influence species composition and abundance, through the control that it exerts over the population dynamics of plant species [4]. Accordingly, it is accepted that goats (Capra hircus) have modified, through selective feeding [5-8], the structure and composition of Mediterranean rangelands, which they have traditionally grazed. Goats are poliphagous animals that feed on a great variety of species, but they always select some species and avoid others [9]. Defoliation is not the only effect that grazing animals exert on vegetation; animals also sit, lie, scratch, and paw on vegetation, breaking the plants and thus also affecting them, especially those of lower breaking resistance $[10,11]$.

The aim of this study was to determine if changes in the abundance of the understory shrub species of a pine forest grazed by goats were related to diet selection of goats. To test this, we analyzed the potential relationship between the diet of a herd of goats during three years and changes in shrub species abundance along this period.

\section{Materials and Methods}

\subsection{Study Area}

The study was carried out in a 100 ha pine forest located in the Doñana Natural Park limits, SW Spain $\left(37^{\circ} 14^{\prime} \mathrm{N}, 6^{\circ} 20^{\prime} \mathrm{W}\right)$. The climate is Mediterranean, with wet and mild win- 
ters and long, dry summers; mean annual rainfall is $540 \mathrm{~mm}$ [8]. The vegetation comprises a Pinus pinea forest with an understory dominated by shrubs (the common species being Cistus salviifolius, Halimium halimifolium, H. calycinum, Myrtus communis, Pistacia lentiscus, and Rosmarinus officinalis). There are some pasture patches between the shrubs dominated by annual species (such as Brachipodium phoenicoides and Ornithopus compresus).

\subsection{Goat Grazing}

The study area is used for timber production and hunting (rabbit and partridge). Grazing by wild (deer) and domestic (goat) herbivores was common until 1970, when deer were removed from the private estate. Goats were excluded in 2002 and reintroduced in 2007. During this five-year period of grazing exclusion, shrub vegetation expanded and grew taller, increasing the pine forest fire risk. The experimental flock comprised 350 adult, female Payoya goats of similar size and age (40-45 kg average weight and three years old). Goats were introduced daily into the study area by a shepherd that moved them around the whole area, daily covering one-third of the available surface, guaranteeing a homogeneous use of the entire study area. The shrub species consumed by goats were determined through direct observation; we followed a modified version of the method described by Meuret et al. [12] and modified by Mancilla-Leytón et al. [13]. During the study period (2007-2010), every month, the goats were observed along three consecutive days. Each day, 10 randomly chosen goats were followed for ten minutes, annotating the number of bites given to each species and the plant part consumed. The abundance of the shrub species in the monthly diet of goats was estimated as the percentage of bites given to each species during the three consecutive sampling dates.

\subsection{Species Abundance}

In February 2007, before the goats were reintroduced into the area, nine $50 \times 50 \mathrm{~m}$ plots ( 0.25 ha each) were randomly placed within the study area and fenced out in order to exclude grazers outside. Five permanent linear transects $25 \mathrm{~m}$ long were established in each exclusion plots and its surrounding area: one inside (9 ungrazed transects) and four outside, in the grazed area, at the N, S, E, and W of the exclusion plot, ten meters apart from the four edges of each plot (36 grazed transects). The abundance of each shrub species was estimated in each transect through the point-intercept method [14], by annotating the species in contact with a stick placed every $10 \mathrm{~cm}$ along the tape. The abundance of the pasture patches was also assessed, without species differentiation. Species were identified according to Valdés et al. [15]. Vegetation was sampled seven times along a three-year grazing period: immediately before the goats entered the area (April 2007), and every six months thereafter (October 2007, April and October 2008, April and October 2009, and April 2010). The abundance of the shrub species in each sampling date and grazing treatment was estimated as the percentage of points corresponding to each species sampled in each of the 9 ungrazed and 36 grazed permanent transects.

\subsection{Data Analysis}

To determine if the abundance of the species influenced their consumption by goats, a G test was performed to compare the shrub species abundance in the grazed area at the beginning of each year with the number of goat bites given to each shrub species throughout the corresponding year. Total annual plant consumption was estimated by adding the bites given to each shrub species during the twelve annual samplings ( 3 days / 2 grazing treatments/2 annual surveys), and these values were compared to species abundance in the grazed area at the beginning of the year (19 study species, Table 1). When test results were significant, the residuals of Habermann [16] were used to determine which species were consumed significantly above or below their abundance. The analyses were carried out with the library car of the R system (R Foundation for Statistical Computing, Vienna, Austria). 
Table 1. Species abundance at the beginning of the study (April 2007), before the goats entered in the area, measured as percentage of total cover. Total goat consumption of each species measured as percentage of bites given to each species in the whole study period (2007-2010). Percentage of change in abundance of the species between the beginning (April 2007) and the end (April 2010) of the study in the ungrazed and in the grazed area.

\begin{tabular}{|c|c|c|c|c|}
\hline \multirow{2}{*}{ Species } & \multirow{2}{*}{$\begin{array}{c}\text { Initial Cover } \\
\%\end{array}$} & \multirow{2}{*}{$\begin{array}{c}\text { Total Consumption } \\
\%\end{array}$} & \multicolumn{2}{|c|}{ Change in Abundance from 2007 to 2010 (\%) } \\
\hline & & & Ungrazed & Grazed \\
\hline Cistus crispus (Cc) & 1.1 & 0.23 & 1.10 & -29.2 \\
\hline Cistus ladanifer $(\mathrm{Cl})$ & 3.0 & 1.19 & 45.6 & -72.2 \\
\hline Cistus libanotis (Cli) & 3.2 & 0.37 & -5.90 & -69.2 \\
\hline Cistus monspeliensis (Cm) & 0.9 & 0.07 & 0.60 & -62.9 \\
\hline Cistus salviifolius (Cs) & 13.3 & 10.14 & -65.5 & -80.6 \\
\hline Halimium calycinum $(\mathrm{Hc})$ & 7.7 & 2.14 & -60.8 & -87.4 \\
\hline Halimium halimifolium $(\mathrm{Hh})$ & 9.4 & 7.61 & -26.9 & -91.1 \\
\hline Helichrysum italicum (Hi) & 1.1 & 0.04 & 161.1 & 19.2 \\
\hline Lavandula stoechas (Ls) & 3.5 & 0.19 & 24.0 & 17.1 \\
\hline Rosmarinus officinalis (Ro) & 14.0 & 2.23 & 66.8 & -18.0 \\
\hline Thymus mastichina (Tm) & 4.3 & 0.00 & 14.9 & 26.6 \\
\hline Daphne gnidium $(D g)$ & 0.7 & 0.00 & 27.8 & -29.3 \\
\hline Erica scoparia (Es) & 5.4 & 4.04 & 25.7 & -21.8 \\
\hline Myrtus communis (Mc) & 9.1 & 43.30 & 30.8 & -30.8 \\
\hline Phillyrea angustifolia $(\mathrm{Pa})$ & 1.2 & 1.10 & 39.7 & 10.4 \\
\hline Pistacia lentiscus (Pl) & 6.6 & 6.63 & 11.7 & -5.90 \\
\hline$Q u e r c u s$ coccifera $(Q c)$ & 4.8 & 3.88 & 17.4 & -34.9 \\
\hline Spiny legumes (spn) & 6.1 & 6.33 & 20.0 & -8.10 \\
\hline Grassland (Grs) & 4.3 & 10.5 & 13.3 & 82.0 \\
\hline
\end{tabular}

The Ivlev's selectivity index " $E$ " [17] was calculated to evaluate diet selectivity variations within each year. The index relates species abundance with species consumption through the following equation: $E i=(r i-p i) /(r i+p i)$, where $r i$ is the proportion of species " $i$ " in the diet, and $p i$ the proportion of species " $I$ " in the grazing area. " $E$ " varies from -1 to 0 for negative selection, and from 0 to +1 for positive selection. The index was calculated seasonally from 2007 to 2010. Seasonal species consumption was estimated as the sum of the bites recorded during the three months of the season (autumn: September, October, and November; winter: December, January, and February; spring: March, April, and May; summer: June, July, and August). Species abundances changed slowly, thus seasonal surveys were not considered necessary. Instead, each April survey was assumed as representative of that year's spring and summer, and autumn and winter seasons were represented by October surveys. In accordance with this, seasonal consumption was compared with plant species abundance registered in the grazed area during the previous representative April/October survey. The Ivlev's index was also used to determine each year's goat grazing preferences as an indicator of the grazing pressure on each species. This annual grazing pressure was compared to the annual abundance change of each species, in order to analyze if changes in species abundances were related with different grazing pressures. The abundance of the species calculated in October was used to compare it with consumption in the autumn and winter seasons, and the abundance of the species calculated in April was used to compare it with consumption in the spring and summer seasons.

\section{Results}

At the beginning of the experiment, before the goats entered the grazing area, twenty shrub species were found in the study area; two of them were dominant (Cistus salviifolius and Rosmarinus officinalis) with over 10\% cover (Table 1). Another four species (Halimium halimifolium, H. calycinum, Myrtus communis, and Pistacia lentiscus) presented a cover between $5 \%$ and $10 \%$, and the rest were less abundant, with a cover below $5 \%$. The pasture, dominated by annual species, was also sparse (less than $5 \%$ cover) (Table 1 ). 
We recorded 88,395 goat bites along the study period; goats browsed the leaves, stem shoots and flowers of all species except Daphne gnidium and Thymus mastichina, which were never consumed (Table 1). They also browsed the fruits of $C$. salviifolius, H. halimifolium, M. communis, P. lentiscus, and Quercus coccifera, and grazed the pasture. The most consumed species was by far M. communis ( $43.8 \%$ of total bites), followed by the pasture $(10.5 \%)$ and C. salviifolius (10.1\%).

The results of the $\mathrm{G}$ tests showed that the goats did not consume the species according to their abundance in any of the three periods of study $(\mathrm{G}=20,578.9,23,555.0$, and $14,875.4$ for 2007/8, 2008/9, and 2009/10, respectively; $\mathrm{df}=18, p<0.000$ ). The analysis of the residuals showed that ten species maintained the same consumption pattern during the three periods of study (Figure 1). M. communis was always significantly consumed well above its abundance, and C. ladanifer, C. libanotis, C. monspeliensis, H. calycinum, Helichrysum italicum, Lavandula stoechas, and R. officinalis were always consumed significantly below their abundance. The majority of these species were not consumed at all during the last period of study (all but R. officinalis). D. gnidium and T. mastichina were never consumed. Six species, C. salviifolius, H. halimifolium, Erica scoparia, Phillyrea angustifolia, P. lentiscus, and $Q$. coccifera, the spiny legumes, and the pasture were significantly consumed above their abundance some years and below or according to their abundance during other periods (Figure 1).
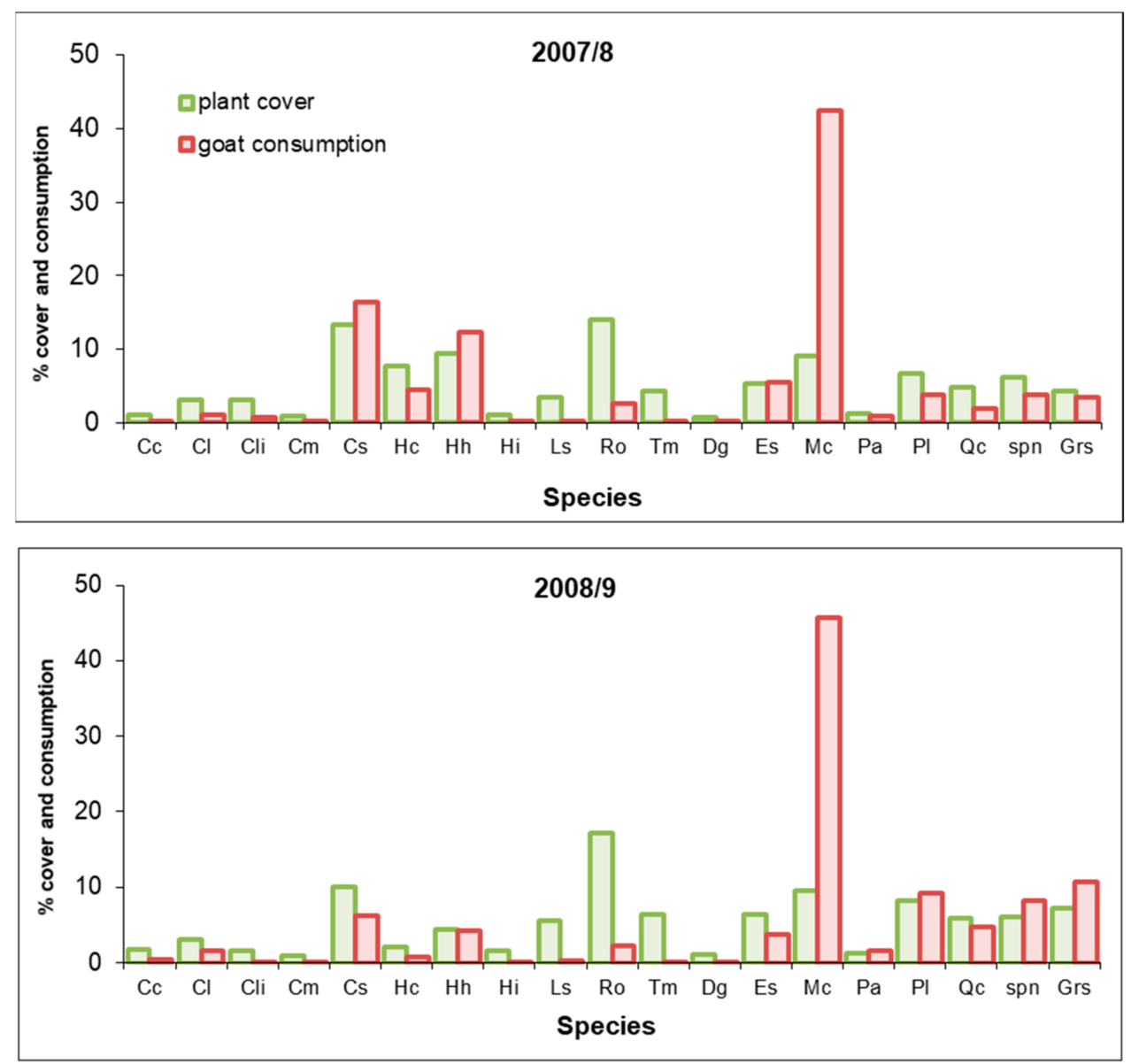

Figure 1. Cont. 


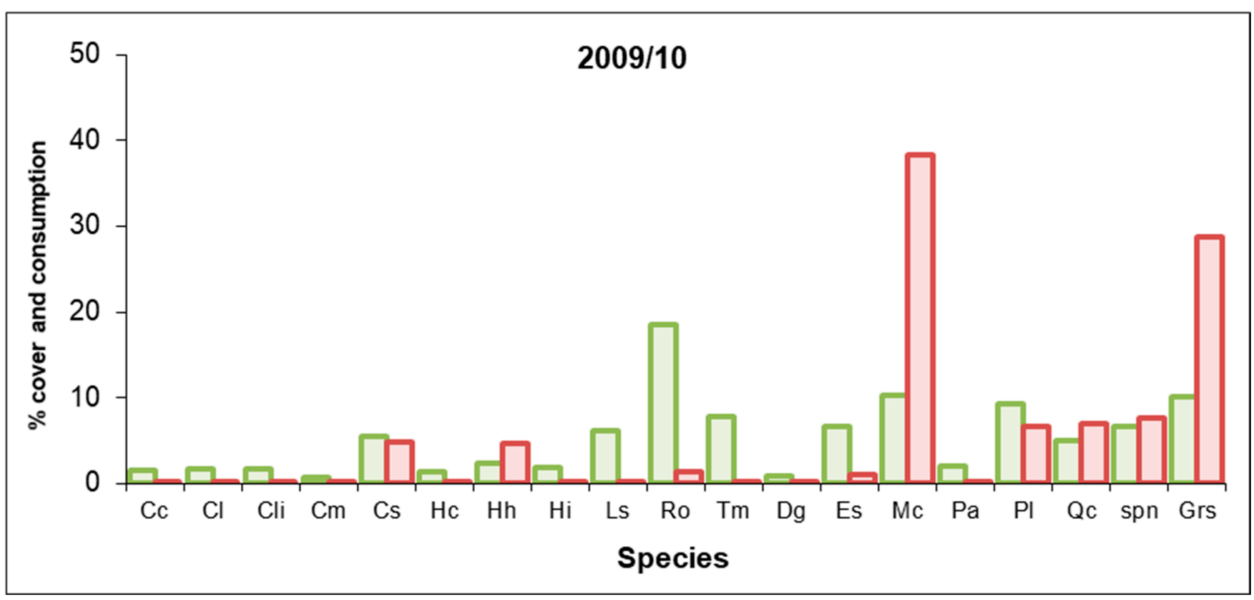

Figure 1. Percentage of cover of each species at the beginning of each year, and percentage of bites given to each species each year. For the names of the species, see Table 1.

The goats' preferences also varied within the years (Figure 2). Certain species tended to be less eaten in spring and summer, such as Cistaceae (with the exception of $C$. libanotis and $H$. calicynum). Other species were only consumed in certain seasons, such as $H$. italicum and R. officinalis, which were only consumed during flowering, or the pasture, which was consumed mainly in winter and spring, when it is green. Many species followed different patterns of seasonal consumption during different years. For instance, P. lentiscus and $Q$. coccifera were only consumed in summer during the third year of study, while E. scoparia was not consumed in spring and summer of this third year. The spiny legumes were consumed during spring of the first two years, and in autumn and winter of the third. M. communis, the most consumed species, was eaten throughout all seasons and years of study.
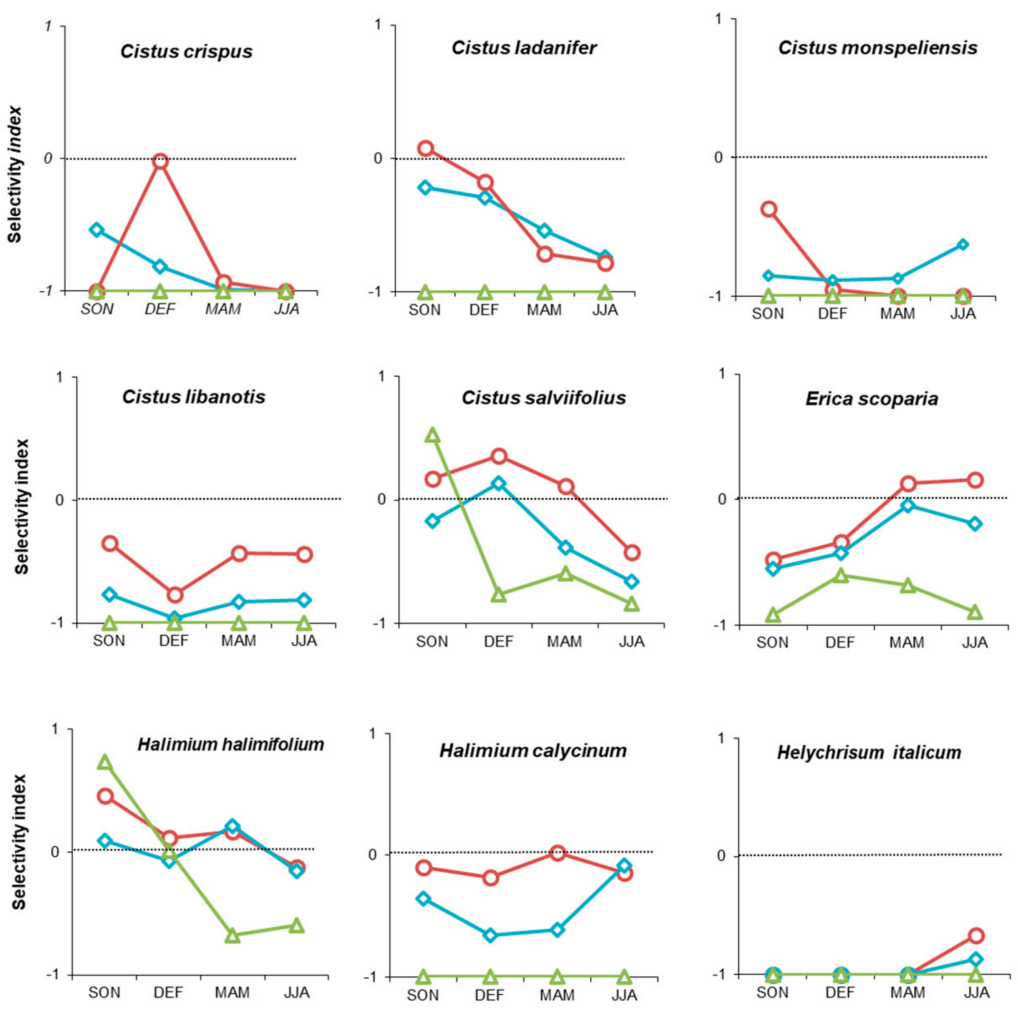

Figure 2. Cont. 

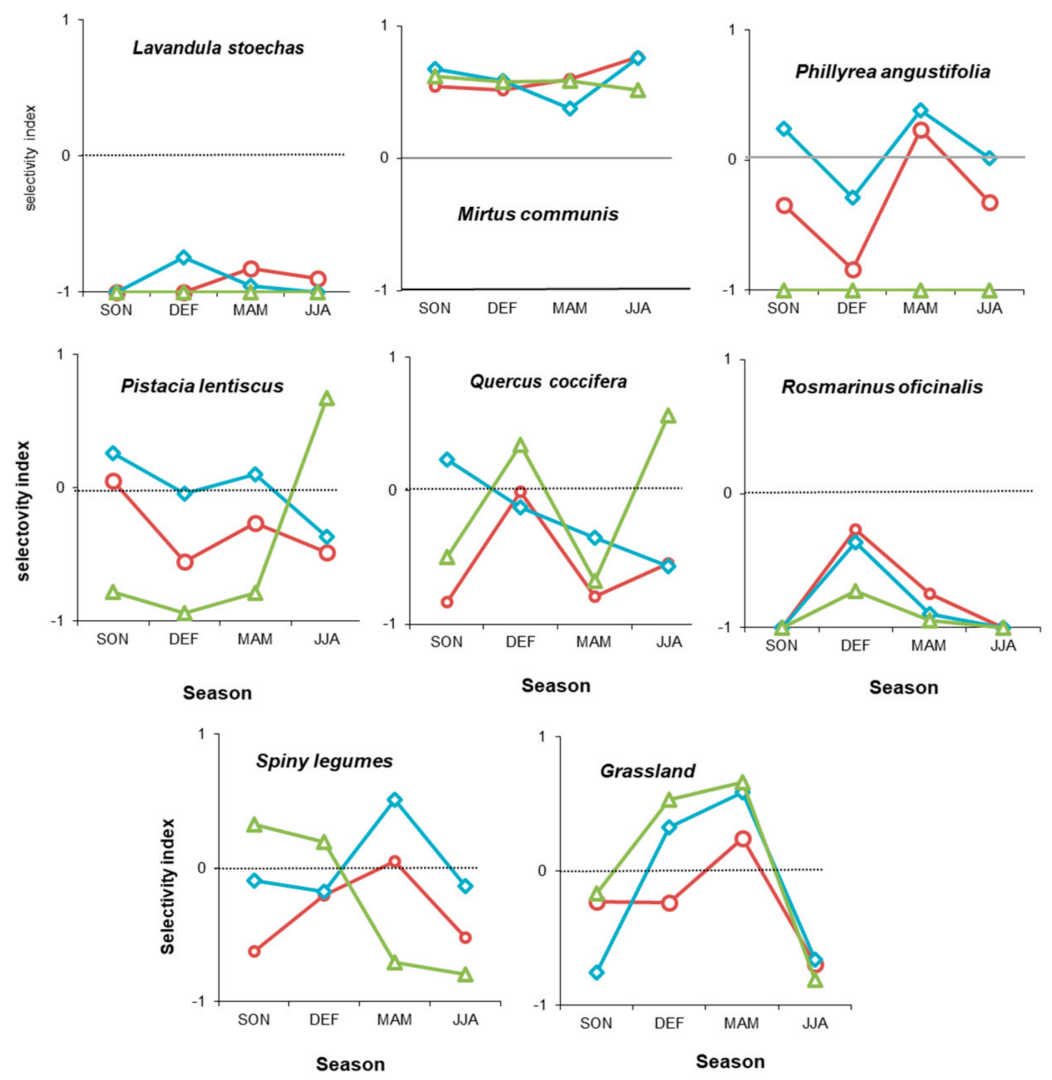

Figure 2. Seasonal species selection by goats measured with Ivlev's index. SNO: autumn (September, October, and November), DEF: winter (December, January, and February). MAM: spring (March,

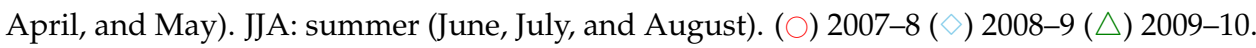

Vegetation cover decreased by $30 \%$ in the grazed areas from the beginning to the end of the study period (Table 1). The abundance of the majority of the species decreased: all but $H$. italicum, T. mastichina, L. stoechas, P. angustifolia, and the pasture. Contrastingly, plant cover slightly increased in the ungrazed area (6.2\%), with most of the species (all but some Cistaceae) increasing in cover or remaining the same. Nine of the twenty studied species followed the same trends of abundance change during the study period in the grazed and ungrazed areas: C. libanotis, C. salviifolius, and Halimium spp. abundance decreased, more in the grazed than in the ungrazed areas, while abundance of H. italicum, L. stoechas, T. mastichina, P. angustifolia, and pasture increased (Table 1).

There was no clear relationship between changes in species abundance and grazing pressure on the species, measured through the selectivity index (Figure 3). The most preferred species, $M$. communis, annually decreased by less than $20 \%$ in cover, the same trend registered for other species such as R. officinalis, E. scoparia, or P. lentiscus, which were consumed below their abundance. The Cistaceae species showed the greatest plant cover decrease, also decreasing in the ungrazed areas. The only species that showed a higher cover reduction when more heavily eaten was Halimium spp. The others did not show any trend of change: their abundance was not affected by consumption intensity. 


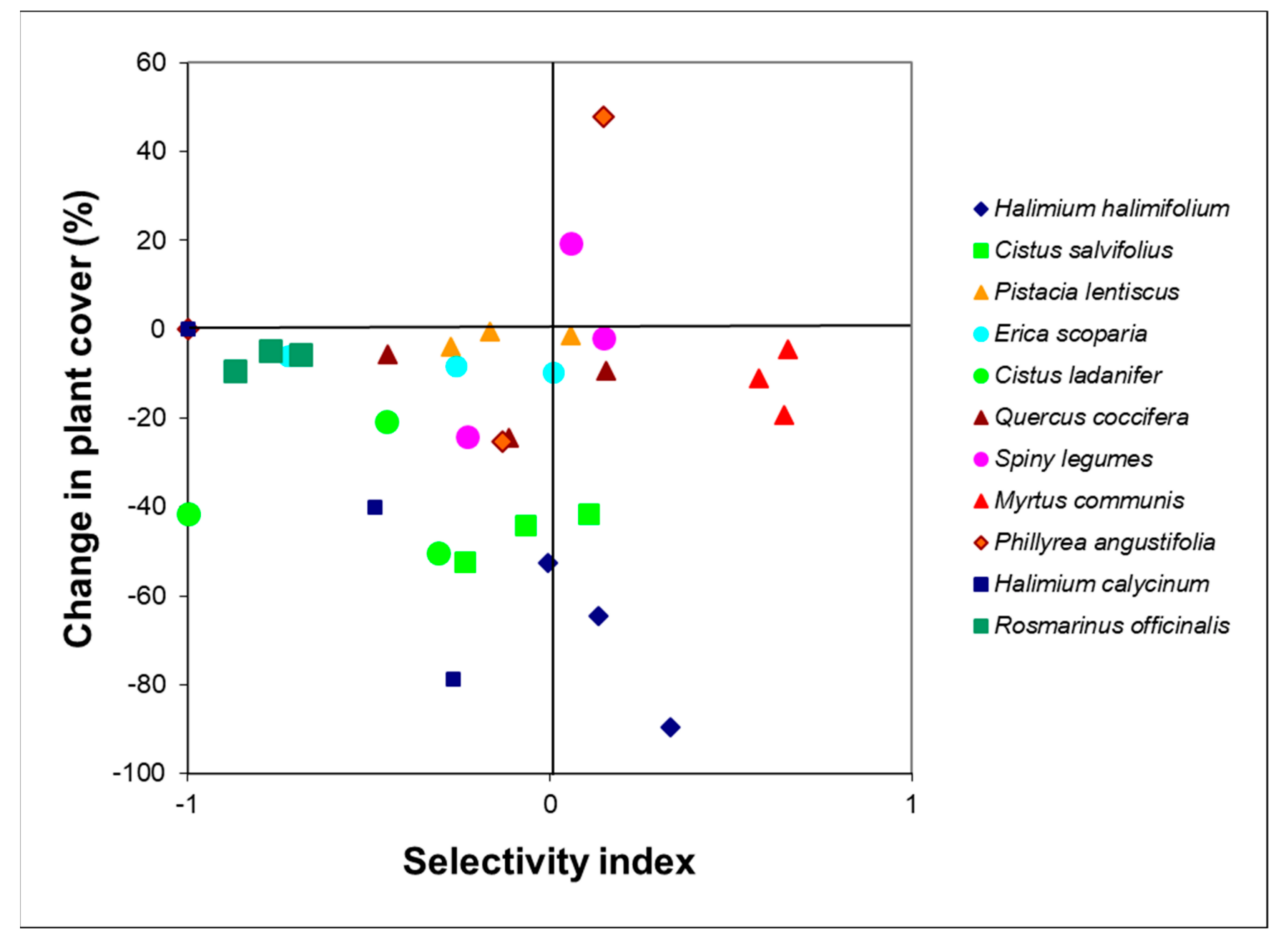

Figure 3. Relationship between selectivity index each year and changes in plant cover this year for each species and year. Only the species that received more than $1 \%$ of the bites of the goats at least in one year have been represented.

\section{Discussion}

During three years of study, goats showed a selective feeding, since they did not browse species according to their abundance; they are selective grazers. A variety of other factors could be supporting this selective behavior, such as chemical characteristics of plants (nutrients, secondary compounds, taste, etc.) or vegetation heterogeneity $[5,18]$, which play an important role in plant function and evolution.

In Mediterranean ecosystems, secondary compounds (tannins, phenols, alkaloids, and other chemical compounds) strongly influence livestock grazing by increasing or diminishing consumption in different species [19], causing different species composition and diversity in grassland and shrubland communities. Grazing is not a random process; goats increased their nutritional value intake ( $\mathrm{N}$ content) while minimizing secondary compounds (tannin and phenol) [20]. Secondary compounds could explain the low consumption of aromatic species such as L. stoechas, R. officinalis, T. mastichina, and H. italicum [21,22], species of the Cistaceae family (C. ladanifer, C. libanotis, C. montpeliensis, and H. calycinum), which are rich in tannins [20], and D. gnidium, a toxic species [23]. Moreover, changes in vegetation heterogeneity as plant cover decreases could be behind the interannual changing preferences for species. A dense understory provides limited amounts of usable forage because it is difficult to penetrate in comparison to a more open shrubland. When the shrubland is thinned, the accessibility to different species changes, perhaps also changing the preferences of the goats. This could explain why $Q$. coccifera and the spiny legumes were consumed below their abundance at the beginning of the study (2007-08 and 2008-09 periods) and above it at the end (2009-10 period). Furthermore, the induction of secondary compounds in the plants by herbivory [24] could explain the interannual changing preferences for species such as C. salviifolius, H. halimifolium, P. angustifolia, and P. lentiscus, which were selected in the first period, refused in the second, and then selected once again. These induced secondary compounds are produced after plant damage, and their production ceases when damage diminishes. Attractive new green shoots in this species cause them to be consumed again. The resprouting capacity of many Mediterranean shrubs has allowed 
them to withstand significant periodic disturbances (i.e., grazing), sprouting vigorously from roots, rhizomes, or stocks, in which they have abundant carbohydrate reserves [13].

The increase in pasture consumption as its cover increases could be related to a selectivity behavior according to abundance. Goats are not exclusively browsers, they are also grazers, preferring grasses over shrubs when they are green and abundant [13]. During grazing, in addition to making a valuable contribution to the mitigation of forest fire risk (control of accumulated biofuel), large herbivores could benefit grassland through soil nutrient enrichment. Feces and urine deposition by grazing animals exerts a positive influence on soil nutrient pools and microbial communities, creating a positive feedback (plant-soil) in grazing areas, especially in N-poor sites, such as Doñana Natural Park [25]. As available pasture increased over time, facilitated by the thinning of the shrubland and the fertilizing effect of goat depositions, goats began to consume it when it was green (winter and spring) over its abundance [18].

Changes in species abundance were poorly related to the preferences of the goats. Species that were consumed significantly below their abundance, such as C. ladanifer, C. libanotis, or C. monspeliensis, notably decreased in the grazed areas and not in the ungrazed ones, while the abundance of the most preferred species, M. communis, decreased much less. Even D. gnidium, which was not consumed at all, reduced its cover in the grazed areas but not in the ungrazed ones. The decline of these species could be related to a special sensibility to damage caused by pawing and scratching of goats [10].

In summary, the goats released into the pine forest fed on a great variety of species, browsing nearly all species available in the understory with different intensities, and also grazing the pasture. However, the changes detected in species abundance were not related to their feeding preferences, suggesting that other effects, such as pawing or scratching, could also be shaping species abundance. Mediterranean shrubland is an ecosystem with a long history of grazing by domestic animals where the flora has co-evolved with large gregarious herbivores that heavily graze vegetation $[7,26]$. In the last decade, grazing has acquired an environmental dimension: control of the understorey vegetation, thus reducing fire risk and increasing forest structural diversity and biodiversity. Differential species selection during grazing could be used in management plans to control the understory vegetation, especially in rural areas, where goat production plays a relevant role [6]. Good management practices in livestock husbandry are key for the residence, sustainability, and preservation of biodiversity in pastoral ecosystems, enhancing silvopastoral systems to reconcile the use of products and services of the natural environment with a guarantee of permanence, in an attempt to pursue ecological, economic, and social stability.

Author Contributions: Conceptualization, Methodology and Formal analysis: J.M.M.-L., R.F.-A., and Á.M.V. Data curation: J.M.M.-L. and R.F.-A. Writing_-Original draft preparation: Á.M.V. and R.F.-A.; Writing editing: Á.M.V. and J.M.M.-L. Supervision, project administration, and funding acquisition: Á.M.V. All authors have read and agreed to the published version of the manuscript.

Funding: This research was funded by Consejería de Medio Ambiente (Junta de Andalucía) (OG-052/07).

Institutional Review Board Statement: The study was conducted according to the "Guiding principles in the care and use of animals" approved by the Council of the American Physiological Society and comply with the current laws of Spain.

Informed Consent Statement: Not applicable.

Data Availability Statement: Not applicable. 
Acknowledgments: The authors wish to thank Doñana Natural Park and Dehesa de Gatos S.L. for the logistic support and field facilities. The authors thank the anonymous reviewers for helpful suggestions concerning presentation of this paper. J.M. Mancilla-Leytón wants to dedicate this manuscript to the memory of Rocío Fernández-Alés, friend, co-worker, outstanding scientist, and coauthor in this research whose ideas trigged the basis for this and several investigations in ecology field, who stood out for her curiosity, passion, and dedication at every moment, R.I.P. J.M. MancillaLeytón gratefully acknowledges an F.P.D.I. grant (Junta de Andalucía). R. F. Lo Faso revised the English version of the manuscript.

Conflicts of Interest: The authors declare no conflict of interest. The funding sponsors had no role in the design of the study, collection, analysis, or interpretation of data, writing of the manuscript, or the decision to publish the results.

\section{References}

1. Food and Agriculture Organization of the United Nations (FAOSTAT). Statistics Database, Crop Statistics. Available online: http:/ / www.fao.org/faostat/en/\#data/QC (accessed on 4 March 2021).

2. Southgate, E.W.R. People and the Land Through Time. Linking Ecology and History; Yale University Press: New Haven, CT, USA, 2019.

3. Naveh, Z.; Lieberman, A.S. Landscape Ecology: Theory and Application; Springer Science and Business Media: New York, NY, USA, 2013.

4. Harper, J.L. Population Biology of Plants; Academic Press: London, UK, 1977.

5. Baraza, E.; Hódar, J.A.; Zamora, R. Consequences of plant-chemical diversity for domestic goat food preference in Mediterranean forests. Acta Oecol. 2009, 35, 117-127. [CrossRef]

6. Morales-Jerrett, E.; Mancilla-Leytón, J.M.; Delgado-Pertíñez, M.; Mena, Y. The contribution of traditional meat goat farming systems to human wellbeing and its importance for the sustainability of this livestock subsector. Sustainability 2020, $12,1181$. [CrossRef]

7. Pareja, J.; Baraza, E.; Ibáñez, M.; Domenech, O.; Bartolomé, J. The role of feral goats in maintaining firebreaks by using attractants. Sustainability 2020, 12, 7144. [CrossRef]

8. Mancilla-Leytón, J.M.; Hernando, C.; Cambrollé, J.; Muñoz-Vallés, S.; Pino-Mejías, R.; MartínVicente, A. Can shrub flammability be affected by goat grazing? Flammability parameters of Mediterranean shrub species under grazing. Sustainability 2021, $13,1555$. [CrossRef]

9. Mancilla-Leytón, J.M.; Parejo-Farnés, C.; Martín Vicente, A. Selection of browse species and energy balance of goats grazing on forest understory vegetation in Doñana Natural Park (SW Spain). Livest. Sci. 2012, 148, 237-242. [CrossRef]

10. Kilgour, R.J. In pursuit of "normal": A review of the behaviour of cattle at pasture. Appl. Anim. Behav. Sci. 2012, 138, 1-11. [CrossRef]

11. Jáuregui, B.; Celaya, R.; García, U.; Osoro, K. Vegetation dynamics in burnt heather-gorse shrublands under different grazing management with sheep and goats. Agrofor. Syst. 2007, 70, 103-111. [CrossRef]

12. Meuret, M.; Bartiaux-Thill, N.; Bourbouze, A. Evaluation de la consommation d'un troupeau de chèvres laitières sur parcours forestier-Méthode d'observation directe des coups de dents-Méthode du marqueur oxyde de chrome. Ann. Zootech. 1985, 34, 159-180. [CrossRef]

13. Mancilla-Leytón, J.M.; Pino Mejías, R.; Martín Vicente, A. Do goats preserve the forest? Evaluating the effects of grazing goats on combustible Mediterranean scrub. Appl. Veg. Sci. 2013, 16, 63-73. [CrossRef]

14. Daget, P.; Poissonet, J. A method of plant analysis of pastures. Ann. Agron. 1971, 22, 5-41.

15. Valdés, B.; Talavera, S.; Fernández-Galiano, E. Flora Vascular de Andalucía Occidental; Ketres Editora: Barcelona, Spain, 1987.

16. Haberman, S.J. The analysis of residuals in cross-classified tables. Biometrics 1973, 29, 205-220. [CrossRef]

17. Ivlev, V.S. Experimental Ecology of the Feeding of Fishes; Yale University Press: New Haven, CT, USA, 1975.

18. Papachristou, T.G.; Dziba, L.E.; Provenza, F.D. Foraging ecology of goats and sheep on wooded rangelands. Small Rumin. Res. 2005, 59, 141-156. [CrossRef]

19. Goetsch, A.L.; Gipson, T.A.; Askar, A.R.; Puchala, R. Invited review: Feeding behavior of goats. J. Anim. Sci. 2010, 88, 361-373. [CrossRef] [PubMed]

20. Mancilla-Leytón, J.M.; Joffre, R.; Martín Vicente, A. Effect of grazing and season on the chemical composition of Mediterranean shrub species in Doñana Natural Park, Spain. J. Arid Environ. 2014, 108, 10-18. [CrossRef]

21. Rogosic, J.; Moe, S.R.; Skobic, D.; Knezovic, Z.; Rozic, I.; Zivkovic, M.; Pavlicevic, J. Effect of supplementation with barley and activated charcoal on intake of biochemically diverse Mediterranean shrubs. Small Rumin. Res. 2009, 81, 79-84. [CrossRef]

22. Vasta, V.; Ventura, V.; Luciano, G.; Andronico, V.; Pagano, R.I.; Scerra, M.; Priolo, A. The volatile compounds in lamb fat are affected by the time of grazing. Meat Sci. 2012, 90, 451-456. [CrossRef] [PubMed]

23. Benítez, G.; González-Tejero, M.R.; Molero-Mesa, J. Knowledge of ethnoveterinary medicine in the Province of Granada, Andalusia, Spain. J. Ethnopharm. 2012, 139, 429-439. [CrossRef] [PubMed]

24. Mithöfer, A.; Boland, W. Plant defense against herbivores: Chemical aspects. Ann. Rev. Plant Biol. 2012, 63, 431-450. [CrossRef] [PubMed] 
25. Mancilla-Leyton, J.M.; Sánchez-Lineros, V.; Martín Vicente, A. Influence of grazing on the decomposition of Pinus pinea L. needles in a silvopastoral system in Doñana, Spain. Plant Soil 2013, 373, 173-181. [CrossRef]

26. Emanuelsson, U. The Rural Landscapes of Europe: How Man Has Shaped European Nature; Swedish Research Council Formas: Värnamo, Sweden, 2009. 